\title{
Investigation of acute toxicity of chlorpyrifos-ethyl on Clarias gariepinus - (Burchell, 1822) using some behavioural indices
}

\author{
Ogueji Emmanuel Okechukwu ${ }^{1 *}$, Ibrahim Baba Usman² and Auta Jehu ${ }^{3}$ \\ ${ }^{1}$ Department Of Biology/Microbiology/Biotechnology, Federal University, Ndufu-Alike, Ikwo, P.M.B 1010, Abakaliki, Ebonyi State, \\ Nigeria. \\ ${ }^{2}$ Department Of Biological Sciences, Faculty Of Natural Sciences, Ibrahim Badamasi Babangida University Lapai, Niger State, \\ Nigeria. \\ ${ }^{3}$ Department Of Biological Science Ahmadu Bello University, Zaria Nigeria. \\ *Corresponding author E-mail: oguejiokey@yahoo.com
}

\begin{abstract}
The impact of short-term exposure to waterborne chlorpyrifos-ethyl on Clarias gariepinus was evaluated through changes of selected behavioural parameters. Fish was exposed to $0.64 \mathrm{mg} / \mathrm{l}, 0.80 \mathrm{mg} / \mathrm{l}, 0.96 \mathrm{mg} / \mathrm{l}, 0.12 \mathrm{mg} / \mathrm{l}, 0.28 \mathrm{mg} / \mathrm{l}$ and control for 96h. The parameters measured were Opercular ventilation (OVC), Tail fin movement rate (TMR), Air gulping index (AGI) and Mortality. The main effects of concentration and duration on rates of tail fin movement rate of fish were highly significant $(\mathrm{p} \leq 0.001)$. There was significant decrease $(\mathrm{p}<0.05)$ in the opercular ventilation of treated fish when compared with control. Also both the main effects of concentration and duration of exposure of chlorpyrifosethyl and the effect of their interactions on AGI were highly significant $(\mathrm{p} \leq 0.001)$. Highest mortality was recorded from $1-12 \mathrm{hrs}$ period of exposure and the mortality at $12 \mathrm{hrs}$ was significantly $(\mathrm{P}<0.05)$ higher than the mortality recorded from 24hrs-96hrs periods. The acute toxicity of chlorpyrifos-ethyl elicited dose and duration dependent behavioural changes that led to mortality of fish. Behavioural changes were therefore proven to be more sensitive endpoints than mortality.
\end{abstract}

Keywords: Acute Toxicity, Behavoural indices, Chlorpyrifos-ethyl, Clarias gariepinus.

\section{Introduction}

Environmental monitoring of pesticides can be for the purpose of generating baseline information, assessing the effects of pesticides to the environment and or continuous measurement of environmental load to ensure that regulatory requirements and standards are being met [14]. According to [11], there are two roles that biomonitoring must play if we are to protect our aquatic resources from damage. (1) We must be able to provide a real-time (i.e. continuous) assessment of present conditions. (2) We must use our biomonitoring technology to predict the effects of new chemical substances likely to reach aquatic ecosystems. In addition, we must use our biomonitoring tools to predict the future ecological effects of chemical substances and utilize this knowledge to prevent these substances from reaching hazardous concentrations in the ecosystem. We must learn how to use laboratory studies on acute effects, chronic studies on growth and reproduction, bioconcentration experiments, behavioural and physiological studies to evaluate chemical substances for their hazard as long-term environmental contaminants. Conveniently, aquatic organisms (fish) serve as integrators of their total environment, and often they respond to extremely low concentrations of environmental contaminants and therefore serve as good candidates for toxicity assays.

In 2000, there were 164 registered products containing Chlorpyrifos [25]. The World Bank and other international organizations have warned that global environmental change may be reaching critical thresholds, and report increasing pressure on land and water resources in many parts of the world. Often these issues affect the poor and impoverished most, undermining the resource base upon which they depend and reducing their prospects for secure and sustainable livelihoods [14].

Chlorpyrifos is an organophosphate insecticide. It is very highly toxic to freshwater fish, estuarine and marine organisms [8]. Typically exposures of about $3 \mathrm{ppm}$ are lethal to fish [15]. Chlorpyrifos is directly toxic to the nervous system and is also transformed inside animals to chlorpyrifos-oxon and 3, 5, 6-trichloro-2-pyridinol (TCP) both of which are many times more toxic to the nervous system than chlorpyrifos itself [10] . Aquatic pollution by pesticides results mainly from their widespread use in agriculture and in vector control campaigns. In Nigeria especially in the 
northern part of the country, there is an upsurge in the application of pesticides in agriculture. A major reason for the increased use of pesticide in the north is the development of dry-season irrigated farming [24]. These poisons are washed into water bodies through surface run-off during the rainy seasons.

The mode of action of chlorpyrifos and their metabolites is inhibition of enzyme acetyl cholinesterase (AchE), and the inhibition of AchE activity caused by chlorpyrifos is more persistent than that caused by other organophosphates and it is believed that this is because chlorpyrifos is lipophilic [9]. They also inhibit other enzymes e.g ATPase, an enzyme important in cellular respiration [34]. In addition, organophosphates are reactive and may cause direct oxidative damage to membranes [17].

For invertebrates, acute LC50 values typically in the $0.1-10 \mu \mathrm{g} / \mathrm{L}$ range and algal endpoints are typically above $100 \mu \mathrm{g} / \mathrm{L}$ [25]. Chronic exposures of aquatic organisms generally results in NOECs of $<1.0 \mu \mathrm{g} / \mathrm{L}$. Some toxic effects in aquatic biota are reversible, whereas others are not, leading to organisms mortality especially the non-target ones. In many cases, toxic effects are reversible only if the organisms can escape the toxicant and migrate to an uncontaminated environment [30]. Fish have an important role in the food chain; therefore, investigation of the effects of pesticides on fish has a diagnostic significance in evaluation of adverse effect of pesticides to human health [5]. Clarias gariepinus is a fresh water fish and an important food supply for humans.

\section{Materials and methods}

Juveniles of Clarias gariepinus was purchased from Maigana fish farm in Zaria, Kaduna State Nigeria. The Clarias species averaging $14.33 \pm 0.50 \mathrm{~cm}$ standard length and body weight of $20.38 \pm 1.25 \mathrm{~g}$ were used for the study. The fish were conveyed to fisheries laboratory in a portable well-aerated white polythene bag containing water from the fish farm. They were held in large water baths of $160 \mathrm{~L}$ capacity at $24.5-25.5^{\circ} \mathrm{C}$ and acclimatized for two weeks in dechlorinated municipal water. During this period, the fishes were fed with pelleted diet containing $35 \%$ crude protein twice per day at $5 \%$ body weight. Also, the water in the glass aquaria was changed once every two days. The fishes were accepted as well as adapted to laboratory conditions when less than 5\% death was recorded for the 14 days period and feeding was discontinued 24 hours before the start of the experimental run [31].

\subsection{Acute/Behavioural Assay}

Acute 96-h static bioassays were conducted in the laboratory following the methods of Sprague [36] and [1]. The nominal concentration for chlorpyrifos-ethyl was $0.64 \mathrm{mg} / 1,0.80 \mathrm{mg} / \mathrm{l}, 0.96 \mathrm{mg} / \mathrm{l}, 0.12 \mathrm{mg} / \mathrm{l}, 0.28 \mathrm{mg} / \mathrm{l}$ and a control with no toxicant. Each concentration was replicated three times. The desired chlorpyrifos concentration was measured and introduced into $25 \mathrm{~L}$ of dechlorinated tap water in the glass aquaria. The mixture was allowed to stand for 30 minutes before introducing test fishes. A total of 180 fish were stocked to give a loading rate of 10 fish per tank. Air gulping index (AGI) was determined by the number of air gulping per tank, divided by the number of fish or surviving fish in the exposed groups. Opercular ventilation and tail fin movement rates were observed for 12, 24, 48, 72 and 96hrs and then counted with a stopwatch and recorded per minute. Survival and mortality were recorded from 1- 12, 24, 48, 72 and 96 hours. Fishes were considered dead when the opercular movement ceased and there was no response to gentle probing. Dead fish were removed immediately. The air gulping index, tail fin beats and opercular beat frequencies were taken every $12 \mathrm{hrs}$.

\subsection{Statistical analysis}

The percentage mortality and probit kill were determined. Graph of probit kill against log concentration, was used to

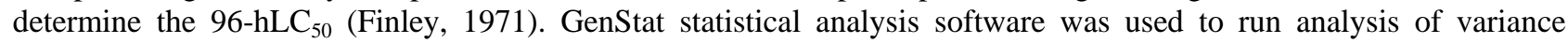
(ANOVA) and Duncan multiple range test (DMRT) was used to test for differences between different levels of treatment and to separate means respectively, were applicable [13]. Test of significance was at the 5\% level of significance.

\section{Results}

\subsection{Mortality}

Analysis of variance (ANOVA) results in Tables $1 \& 2$ showed that control, recorded no mortality. However, mortality was significantly dose-dependent $(\mathrm{p}<0.05)$ in the treated fish. Also highest mortality was recorded from $1-12 \mathrm{hrs}$ period 
of exposure and the mortality at $12 \mathrm{hrs}$ was significantly higher than the mortality recorded from $24 \mathrm{hrs}-96 \mathrm{hrs}$ periods. Surviving fish after $48 \mathrm{hrs}$ did not die up to the end of $96 \mathrm{hr}$ period (Table 2).

\subsection{No Observed Effect Level (NOEL)}

Laboratory $96-\mathrm{h} \mathrm{LC}_{50}$ was estimated to be $0.92 \mathrm{mg} / \mathrm{l}$ and the NOEL is $0.0092 \mathrm{mg} / \mathrm{l}$. These values will serve as a guide to the limit expected in our streams, rivers and fish ponds.

\subsection{Opercular Ventilation (OVC)}

There was significant decrease $(\mathrm{p}<0.05)$ in the opercular ventilation of exposed fish when compared with control (Table 2). Exposure time of $12 \mathrm{hrs}$ recorded significantly highest OVC values when compared with other exposure periods, while $24 \mathrm{hrs}$ recorded the lowest. There was a duration-dependent increase in OVC value from $48 \mathrm{hrs}$ to $96 \mathrm{hrs}$.

\subsection{Tail fin Movement Rate (TMR)}

The control value of TMR was significantly higher $(\mathrm{p}<0.05)$ than treated fish $($ Table $1 \& 2)$. There was no clear trend in the TMR values among the treated fish. However, exposure time of $12 \mathrm{hrs}$ recorded significantly highest TMR ( $\mathrm{p}<0.05$ ), while $24 \mathrm{hr}$ exposure recorded the lowest value (Table 2). The main effects of concentration and duration on rates of tail fin movement rate of fish were highly significant $(\mathrm{p} \leq 0.001)$. The interaction of these two factors also had highly significant effect on tail fin movement rates $(\mathrm{p}=0.003)$. When the treatment means for concentration were compared using the Duncan's multiple range test, the control value of TMR was significantly higher than those of treated fish from 24-96 hour durations (Table 3). Tail fin movement rates were similar in treated fish from 24-96 hour periods and were in the 85.33-97.4 range (Table 2). Across concentrations, however, the highest TMR was recorded in the first 12 hours of exposure of fish to the pesticide. TMR dropped significantly by the $24^{\text {th }}$ hour of exposure, although it rose significantly thereafter, being comparable in the $48^{\text {th }}-96^{\text {th }}$ hour periods. When the interactions of concentration and time were considered (Table 3) the highest tail fin movement rates were observed in the first 12 hours after exposure for all concentrations of chlorpyrifos-ethyl.

\subsection{Air gulping index (AGI)}

Both the main effects of concentration and time of chlorpyrifos-ethyl and the effect of their interactions on AGI were highly significant $(\mathrm{p} \leq 0.001)$. AGI was highest at the highest nominal concentrations and in the first 12 and 24 hours of exposure (Table $1 \& 2$ ). When fish mortality values were plotted against air gulping index (AGI), the coefficient of determination suggested that only $39.9 \%$ of mortalities can be predicted through a linear relationship with AGI (Figure 2). This trend was positive, showing that fish mortality increased with increasing air gulping index. However, when mortality was plotted against opercular ventilation count, a linear relationship with a negative slope was obtained (Figure 3). This shows that mortality for fish reduced with decreased rates of opercular ventilation for fish exposed to acute nominal concentrations of chlorpyrifos- ethyl.

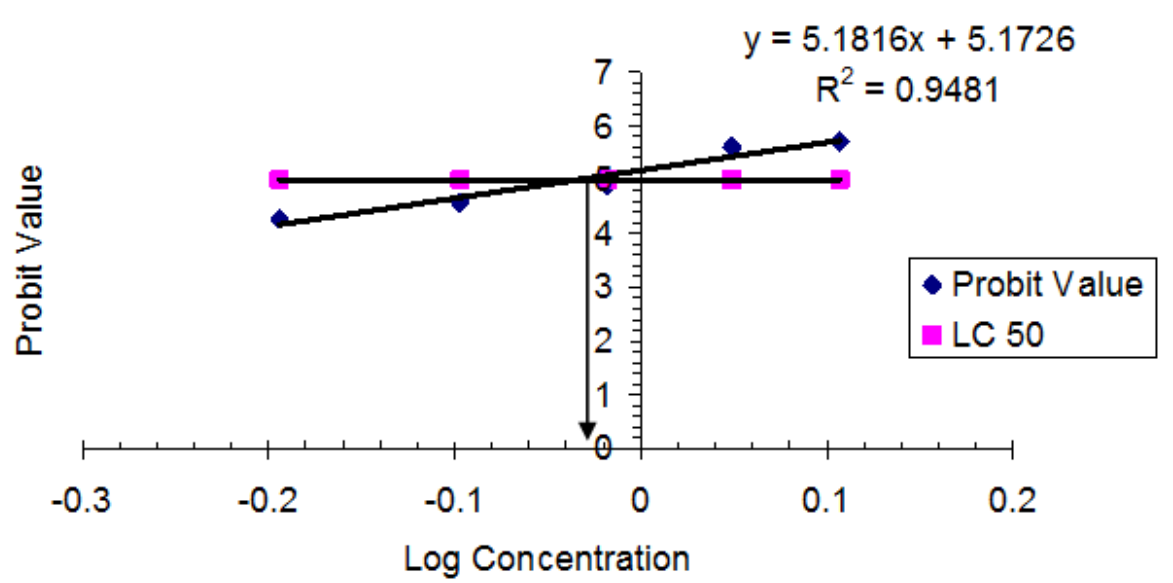

Fig 1: 96h LC50 of chlorpyrifos-ethyl for juveniles of Clarias gariepinus 
Table 1: The Effect of Acute Doses of Chlorpyrifos-ethyl on some Behaviour Indices of C. gariepinus in 96hrs.

\begin{tabular}{ccccc}
\hline Conc. $(\mathrm{mg} / \mathrm{l})$ & Mortality & Air Gulping Index & Opercula Vent.Count & Tail Fin Movement Rate \\
\hline 0.00 & $0 \pm 0.00^{\mathrm{d}}$ & $0.40 \pm 0.12^{\mathrm{d}}$ & $52.00 \pm 6.30^{\mathrm{a}}$ & $116.40 \pm 4.25^{\mathrm{a}}$ \\
0.64 & $0.47 \pm 0.83^{\mathrm{c}}$ & $0.46 \pm 0.16^{\mathrm{d}}$ & $49.20 \pm 4.34^{\mathrm{b}}$ & $91.46 \pm 22.83^{\mathrm{bc}}$ \\
0.80 & $0.66 \pm 1.23^{\mathrm{bc}}$ & $0.92 \pm 0.18^{\mathrm{a}}$ & $47.40 \pm 5.52^{\mathrm{c}}$ & $85.33 \pm 28.02^{\mathrm{c}}$ \\
0.96 & $0.93 \pm 1.38^{\mathrm{b}}$ & $0.74 \pm 0.17^{\mathrm{b}}$ & $49.20 \pm 10.89^{\mathrm{c}}$ & $93.13 \pm 23.68^{\mathrm{bc}}$ \\
1.12 & $1.46 \pm 2.72^{\mathrm{a}}$ & $0.64 \pm 0.26^{\mathrm{c}}$ & $48.00 \pm 10.54^{\mathrm{bc}}$ & $93.00 \pm 25.55^{\mathrm{bc}}$ \\
1.28 & $1.53 \pm 2.55^{\mathrm{a}}$ & $0.90 \pm 0.24^{\mathrm{a}}$ & $48.40 \pm 10.78^{\mathrm{bc}}$ & $97.40 \pm 20.66^{\mathrm{b}}$ \\
\hline
\end{tabular}

Means with the same superscript along columns are not significantly different $(\mathrm{p}<0.05)$

(Mean values \pm SD) $n=15$

Table 2: The Duration Effect of Acute Doses of Chlorpyrifos-ethyl on some Behaviour Indices of C. gariepinus in 96hrs.

\begin{tabular}{ccccc}
\hline Time (hrs) & Mortality & Air Gulping Index & Opercula Vent. Count & Tail Fin Movement Rate \\
\hline 12 & $3.50 \pm 2.52^{\mathrm{a}}$ & $0.76 \pm 0.28^{\mathrm{a}}$ & $55.50 \pm 10.60^{\mathrm{a}}$ & $135.66 \pm 6.57^{\mathrm{a}}$ \\
24 & $0.50 \pm 0.61^{\mathrm{b}}$ & $0.82 \pm 0.32^{\mathrm{a}}$ & $39.66 \pm 7.26^{\mathrm{d}}$ & $77.66 \pm 18.49^{\mathrm{c}}$ \\
48 & $0.22 \pm 0.42^{\mathrm{bc}}$ & $0.65 \pm 0.16^{\mathrm{b}}$ & $48.66 \pm 6.44^{\mathrm{c}}$ & $89.11 \pm 12.25^{\mathrm{b}}$ \\
72 & $0.00 \pm 0.00^{\mathrm{c}}$ & $0.55 \pm 0.26^{\mathrm{c}}$ & $49.00 \pm 2.45^{\mathrm{c}}$ & $88.38 \pm 11.78^{\mathrm{b}}$ \\
96 & $0.00 \pm 0.00^{\mathrm{c}}$ & $0.60 \pm 0.26^{\mathrm{bc}}$ & $52.33 \pm 2.89^{\mathrm{b}}$ & $95.33 \pm 10.07^{\mathrm{b}}$ \\
\hline
\end{tabular}

Means with the same superscript along columns are not significantly different $(\mathrm{p}<0.05)$

(Mean values $+\mathrm{SD}$ ) $\mathrm{n}=18$

Table 3: Duration Interaction Effect with Acute Nominal Doses of Chlorpyrifos-ethyl on C. gariepinus Tail fin Movement Rate

\begin{tabular}{|c|c|c|c|c|c|}
\hline \multirow[b]{2}{*}{ Conc.(mg/L) } & \multicolumn{5}{|c|}{ Time (hrs) / tail fin movement rate. } \\
\hline & 12 & 24 & 48 & 72 & 96 \\
\hline 0.00 & $124.00 \pm 1.15^{\mathrm{abc}}$ & $114.00 \pm 1.15^{\mathrm{bcd}}$ & $115.00 \pm 0.57^{\text {bcd }}$ & $113.00 \pm 0.57^{\mathrm{bcd}}$ & $116.00 \pm 0.57^{\mathrm{bc}}$ \\
\hline 0.64 & $132.00 \pm 0.57^{\mathrm{ab}}$ & $69.00 \pm 1.15^{\mathrm{gh}}$ & $80.00 \pm 1.15^{\mathrm{fg}}$ & $80.30 \pm 0.33^{\mathrm{fg}}$ & $96.00 \pm 1.15^{\mathrm{def}}$ \\
\hline 0.80 & $109.70 \pm 33.35^{\text {cde }}$ & $58.00 \pm 1.15^{\mathrm{h}}$ & $82.00 \pm 1.15^{\mathrm{fg}}$ & $83.00 \pm 0.57^{\mathrm{fg}}$ & $94.00 \pm 1.15^{\mathrm{ef}}$ \\
\hline 0.96 & $137.00 \pm 0.57^{\mathrm{a}}$ & $70.00 \pm 0.57^{\mathrm{gh}}$ & $84.70 \pm 0.88^{\mathrm{fg}}$ & $85.00 \pm 0.57^{\mathrm{fg}}$ & $89.00 \pm 0.57^{\mathrm{fg}}$ \\
\hline 1.12 & $141.00 \pm 0.57^{\mathrm{a}}$ & $71.00 \pm 0.57^{\mathrm{gh}}$ & $86.00 \pm 1.15^{\mathrm{fg}}$ & $80.00 \pm 0.57^{\mathrm{fg}}$ & $87.00 \pm 0.57^{\mathrm{fg}}$ \\
\hline 1.28 & $137.00 \pm 1.15^{\mathrm{a}}$ & $84.00 \pm 1.15^{\mathrm{fg}}$ & $87.00 \pm 1.15^{\mathrm{fg}}$ & $89.00 \pm 1.15^{\mathrm{fg}}$ & $90.00 \pm 0.57^{\mathrm{ef}}$ \\
\hline
\end{tabular}

Means with the same alphabet along columns are not significantly different $(\mathrm{p}<0.05)$. (Mean values \pm SE) $n=3$

Table 4: Duration Interaction Effect with Acute Doses of Chlorpyrifos-ethyl on C. gariepinus Air gulping index

\begin{tabular}{|c|c|c|c|c|c|}
\hline \multirow[b]{2}{*}{ Conc.(mg/L) } & \multicolumn{5}{|c|}{ Time (hrs) / Air gulping index } \\
\hline & 12 & 24 & 48 & 72 & 96 \\
\hline $0.00($ Control $)$ & $0.30+0.06^{\mathrm{f}}$ & $0.30 \pm 0.05^{\mathrm{f}}$ & $0.50+0.05^{\mathrm{def}}$ & $0.50+0.06^{\mathrm{def}}$ & $0.40 \pm 0.05^{\mathrm{ef}}$ \\
\hline 0.64 & $0.60 \pm 0.05^{\mathrm{cde}}$ & $0.60 \pm 0.05^{\mathrm{cde}}$ & $0.50 \pm 0.06^{\mathrm{def}}$ & $0.30 \pm 0.05^{\mathrm{f}}$ & $0.30 \pm 0.05^{\mathrm{f}}$ \\
\hline 0.80 & $0.80 \pm 0.05^{\mathrm{bc}}$ & $1.00 \pm 0.12^{\mathrm{ab}}$ & $0.80 \pm 0.12^{b c}$ & $1.00 \pm 0.11^{\mathrm{ab}}$ & $1.00 \pm 0.11^{\mathrm{ab}}$ \\
\hline 0.96 & $1.00 \pm 0.00^{\mathrm{ab}}$ & $0.80 \pm 0.05^{\mathrm{bc}}$ & $0.70 \pm 0.05^{\mathrm{cd}}$ & $0.60 \pm 0.05^{\mathrm{cde}}$ & $0.60 \pm 0.05^{\mathrm{cde}}$ \\
\hline 1.12 & $0.80 \pm 0.05^{\mathrm{bc}}$ & $1.00 \pm 0.05^{\mathrm{ab}}$ & $0.60 \pm 0.06^{\mathrm{cde}}$ & $0.30 \pm 0.05^{\mathrm{f}}$ & $0.50 \pm 0.05^{\mathrm{def}}$ \\
\hline 1.28 & $1.10 \pm 0.05^{\mathrm{a}}$ & $1.20 \pm 0.06^{\mathrm{a}}$ & $0.80 \pm 0.05^{\mathrm{bc}}$ & $0.60 \pm 0.05^{\mathrm{d}}$ & $0.80 \pm 0.05^{\mathrm{bc}}$ \\
\hline
\end{tabular}

Means with the same alphabet along columns are not significantly different $(p<0.05)$. (Mean values $\pm S E) n=3$ 


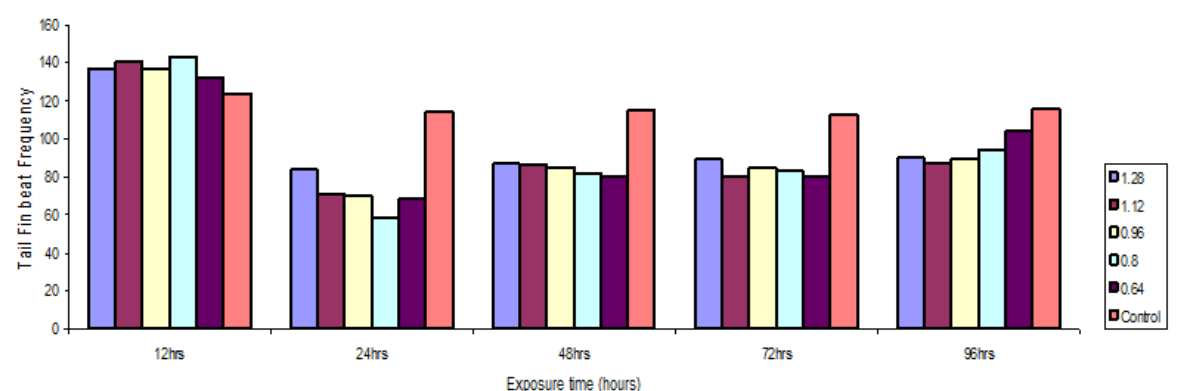

Figure 2: Tailfin beat frequency of $C$. gariepinus exposed to acute nominal concentrations of chlorpyrifos ethyl

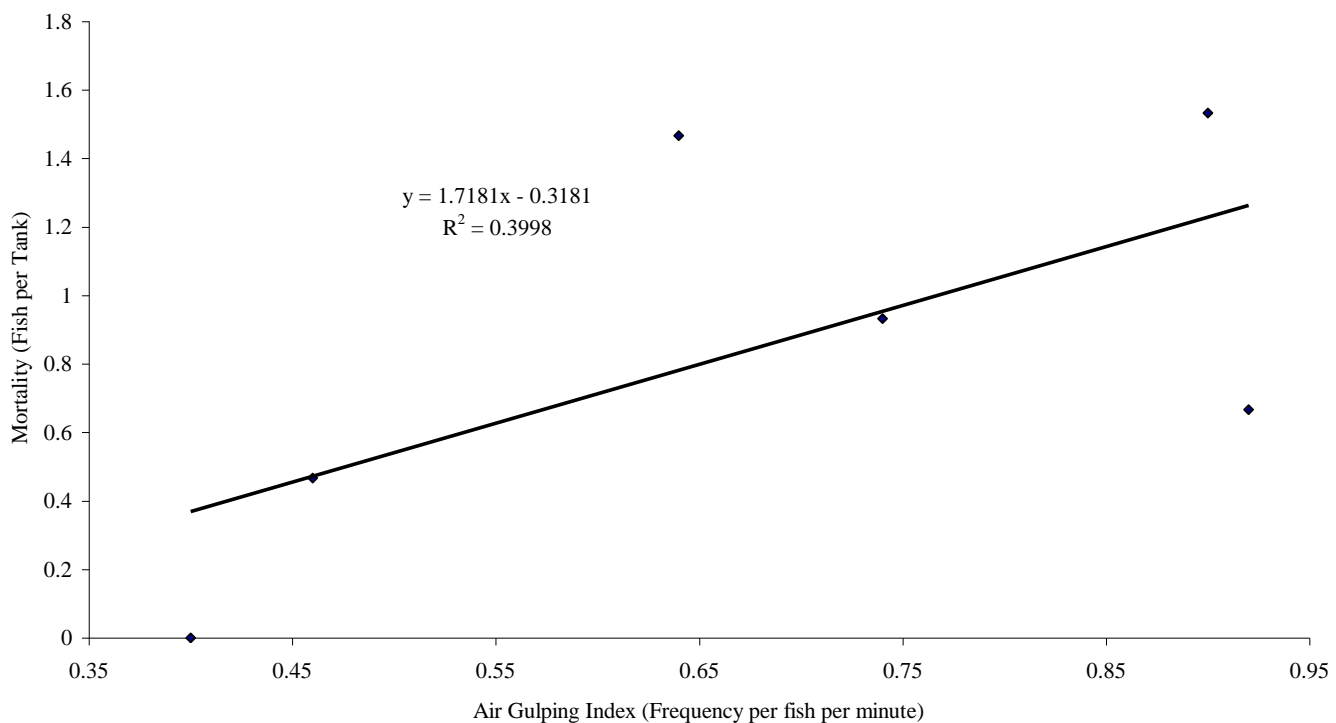

Figure 3: Trends for mortality of $C$. gariepinus against air gulping index after exposure to concentrations of chlorpyrifos-ethyl

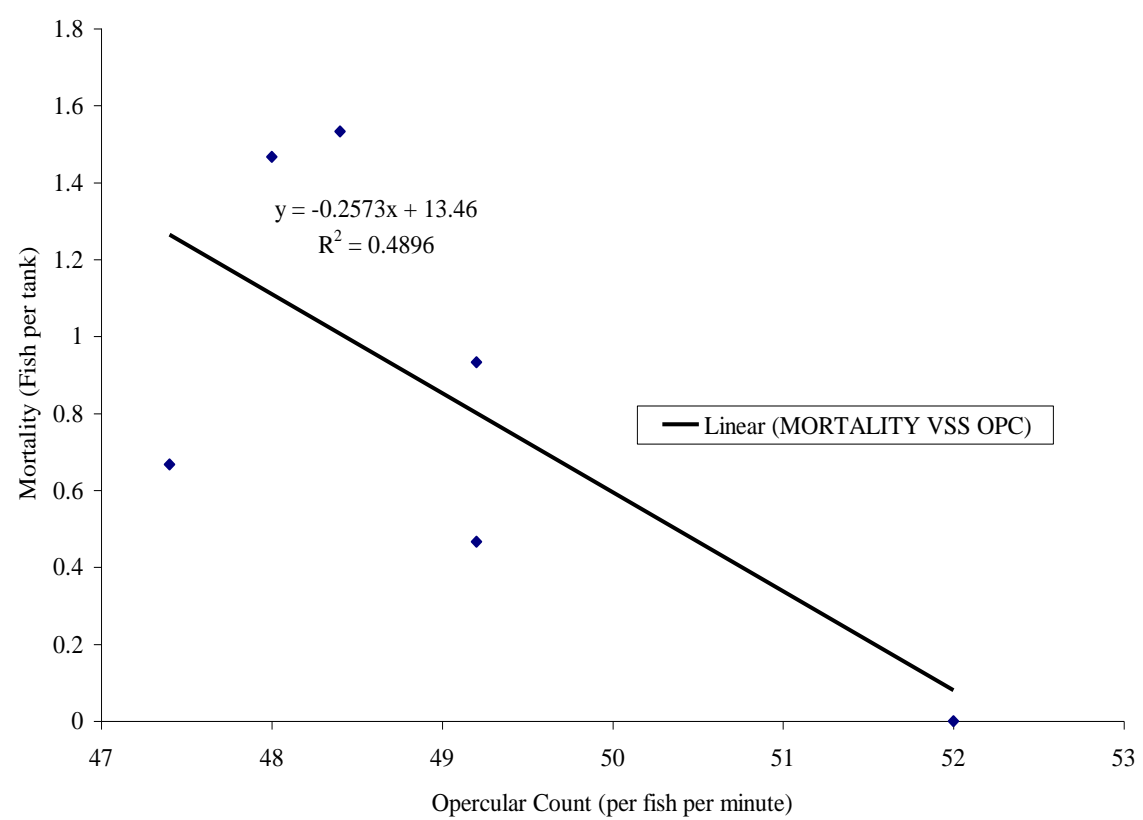

Figure 4: Trends for mortality of C. gariepinus against counts of opercular ${ }^{-}$movements at nominal concentrations of chlorpyrifos ethyl 


\section{Discussion}

From 1-12hrs of exposure, fish behaviour was marked by hyperactivity and increased aggression, this was reflected in the elevated OVC and TMR within the period. The OVC and TMR progressively decreased as fish became severely intoxicated in $24 \mathrm{hrs}$. Highest mortalities was recorded between 1-24hrs and from 72-96hrs, surviving fish had become adapted to the new environment. Occasionally there was breakage of vertebral bone at the middle and caudal region due to abnormal vertebral bending. Also swollen abdomen was occasionally observed. These morphological alterations were restricted to the two highest nominal concentrations of $1.12 \mathrm{mg} / \mathrm{l}$ and $1.28 \mathrm{mg} / \mathrm{l} \mathrm{respectively.} \mathrm{Others} \mathrm{include}$ continuous forward posturing of the pectoral and pelvic fins. The time of initial onset of morphological responses and mortality was dose-dependent. Fish exposed to nominal concentrations held their pectoral and pelvic fins at $45^{\circ}$ to $90^{\circ}$ angles from their body with little or no movement. The dorsal and ventral fins were also fully stretched even when fish was in resting position. Chlorpyrifos is an organophosphorus insecticide that causes the inhibition of AChE. Excess acetylcholine causes continuous firing of muscle fibers [8]. [12] reported that fish exposed to any one of several AChE inhibitors showed common tetany, lordosis and scoliosis. The abnormal vertebral bending observed in this investigation may have led to the occasional breakages at the middle and caudal regions of the fish. [20] recorded 50\% deformities, which consisted of lateral bend in the spine; in fathead minnows after $15 \mathrm{hrs}$ of $0.122 \mathrm{mg} / \mathrm{l}$ chlorpyrifos exposure. [19] also noted spinal deformities in $P$. promelas and $O$. mykiss. The behavioural and morphological alterations observed in C.gariepinus were consistent with the findings of [12], [20] and [19].

[32] reported that residue levels of chlorpyrifos in surviving O. latipes at $48 \mathrm{hrs}$ exposure were 727 to 1,143 times greater than the water concentrations. Similarly [35] reported rapid accumulation of radio labeled chlorpyrifos in $C$ .auratus during the first $10 \mathrm{hrs}$ of exposure, and the maximum levels were reached within $12 \mathrm{hrs}$. Though in the current investigation, bioaccumulation and bioconcentration studies was not undertaken, but our OVC and TMR had the lowest significant values in $24 \mathrm{hrs}$ exposure suggesting possibly that surviving fish was maximally intoxicated at this period due to maximum bioconcentration and bioaccumulation and AChE inhibition. The effect of certain pesticides on the activity of acetylcholinestrase may lead to decrease mobility in fish [6]. Although the effect of chlorpyrifos-ethyl on acetylcholinestrase is not known, it has been found to inhibit this enzyme in acute toxicity tests of fish exposed to very low concentrations [16]. In this study, the OVC and TMR per minutes were used as a measure of respiratory rate as recommended by [22]. The results clearly showed a marked increase in opercular ventilation and tail fin beats per minute as the exposed fish needed more oxygen for the increased metabolic rate especially within $12 \mathrm{hrs}$ of exposure. This behaviour suggests respiratory impairment, probably due to the hypoxic environment of the toxicant and the effect on the gill and the body physiological processes. This is in line with the findings of [27]. [22] also reported that an increase in oxygen consumption may be associated with additional energy requirements for detoxification or it may be caused by the extra activity necessary for an avoidance reaction to the toxicant and also, an attempt to escape from the toxicant environment. The reduction in opercular and tail fin beats with time of exposure suggested decrease in oxygen consumption and reduction of respiratory rate. The reduction in respiratory rate would suggest that the fish had become fatigued due to several attempts to escape from the toxic medium or frequent surfacing to facilitate more oxygen intake. Similar findings were observed by [21], [2]. Regardless of the mechanism associated with the TMR decrease, such effects on swimming performance could increase an individual's vulnerability to predation, decrease its ability to capture food items and decrease the energy available for growth [7].

The duration dependent increase in OVC and TMR from 24hrs to $96 \mathrm{hrs}$ may be due to loss of chlorpyrifos from the aquaria tanks through volatilization, fish adaptation or its detoxification by the fish. [4] reported that in most experiments, BCF's equilibrium for chlorpyrifos was quickly achieved and that residue was rapidly depurated in clean water with typical half-lives of about 2 days. Chlorpyrifos is quickly metabolized and detoxified by fish and aquatic invertebrates and subsequently does not remain in the food chain [4]. Volatility half-lives of 3.5 and 20 days have been estimated for pond water [29].

The mortality values and the 96-hLC50 of C. gariepinus exposed to acute concentrations of chlorpyrifos-ethyl was $0.92 \mathrm{mgl}-1$ (Fig 1) and showed the pesticide to be highly toxic to fish. The 96hLC50 value is consistent with findings of other authors. [16] reported the 96-hour LC50 for chlorpyrifos was $0.009 \mathrm{mg} / \mathrm{l}$ in mature rainbow trout, $0.098 \mathrm{mg} / \mathrm{l}$ in lake trout, $0.806 \mathrm{mg} / \mathrm{l}$ in goldfish, $0.01 \mathrm{mg} / \mathrm{l}$ in bluegill and $0.331 \mathrm{mg} / \mathrm{l}$ in fathead minnow. [23] reported that hyperactivity is a primary and principal sign of nervous system failure due to pesticide poisoning, which affects physiological and biochemical activities. [28] also reported that disruption of the functioning of nervous system of fish might be the cause of slow and lethargic swimming, erratic movement and loss of equilibrium. Similar observations were made by [26], [33] and [3]. 


\section{Conclusion}

A distinguishing behaviour or set of behavioral and morphological symptoms was observed for Chlorpyrifos-ethyl against control. Changes in behaviour and morphology were proven to be more sensitive endpoints than was mortality. Clarias gariepinus and the selected morphological and behavioural symptoms may be useful for monitoring effluents, for predicting the mode of action of unknown pesticides, and for testing water from wastewater treatment facilities before its discharge. The results of our study also suggest that acute exposure of $C$. garipinus to chlorpyrifos-ethyl could lead to alterations in carbohydrate and lipid metabolism and possible organ damage. In the light of the above observations, it is recommended that chlorpyrifos-ethyl should be used with caution and in a sustainable manner, as it could be hazardous to aquatic biota, domestic animals and human beings as well.

\section{References}

[1] American Public Health Association (APHA), American Water Works Association (AWWA) and Water Environment Federation (WEF), (1992). Standard Methods for the examination of Water and Wastewater, 18th Edition; Washington, D.C.

[2] J. Auta, Toxicity of Dimethoate to juveniles of Oreochromis niloticus (Trewaivas) and Clarias gariepinus (Teugels) (2001). Ph.D Thesis, Biological Sciences Department, Ahmadu Bello University, Zaria, Nigeria.

[3] J. Auta, J. K. Balogun, M. L. Balarabe, T.T. Gbem, The susceptibility of juveniles of Clarias gariepinus (Teugels) to dimethoate and Galex: Two pesticides commonly used in Nigeria. Chem class Journal 2 (2004) $145-149$.

[4] M.G. Barron, K.B. Woodburn, Ecotoxicology of chlorpyrifos. In Review of Environmental Contamination \& Toxicology (1995) 1-93, Springer, New York.

[5] G. Begum, S.Vijayaraghavan, Alterations in protein metabolism of muscle tissue in the fish Clarias batrachus (Linn) by commercial grade dimethoate. Bull.of Environ. Comtam. And Toxicol. 57 (1996) 223-228.

[6] S. Bretaud, J.P.Toutant, P. Saglio, Effects of carbofuran, diuron and nicosulfuron on acetylcholinesterase activity in goldfish (Carassius auratus). Ecotoxicol. Environ. Saf. 47 (2000) 117-124.

[7] R.W. Carlson, S.P. Bradbury, R.A. Drummond, D.E. Hammermesiter, Neurological effects on startle response and escape from predation by medaka exposed to organic chemicals. Aquat. Toxicol. 43(1998) 51-68.

[8] C. Cox, Chlorpyrifos, Part1: Toxicology. Journal of Pesticide Reform, 14(4) (1995) 95-20

[9] J.E. Chambers, R.L. Carr, Inhibition patterns of brain acetylcholisnesterase, hepatic and plasma aliesterases following exposures to three phosphorothionate insecticides and their oxons in rats. Fund. Appl. Toxicol. 21(1993) 111-119.

[10] J.E. Chambers, C.S. Forsyth, H.W. Chamber, Bioactivation and detoxification of organophosphorus insecticides in rat brains. In Caldwell, J., Hutson D.H., and Paulson. G.D. Intermediary xenobiotic metabolism: Methodology, mechanisms and significance, Basingstoke, U.K: Taylor and Francis. (1989) 99-115.

[11] K.L. Dickson, G. David, K. Christine, L. Kenneth, Biological Monitoring to provide an Early Warning of Environmental Contaminants. In: Biological Monitoring for Environmental Effects Lexington Books, Massachusetts Toronto (1980) 53-74.

[12] R.A. Drummond, C.L. Russom, D.L. Gieger, D.L.DeFoe, Behavioral and morphological changes in fathead minnow (Pimephales romelas) as diagnostic endpoints for screening chemicals according to mode of action. In T.M. Poston and R. Prudy, eds., Aquatic Toxicology and Environmental Fate: Ninth Volume. STP 921. American Society for Testing and Material, Philadelphia, PA, (1986) $415-435$.

[13] D.B. Duncan, Multiple range tests. Biometric, 11 (1955) 1-42

[14] E.I.A. Training Resource Manual. Topic 7: Mitigation and Impact Management. Second Edition ( 2002).

[15] E.P.A. Pesticide fact sheet, Chlorpyrifos. No. 37. Washington, D.C. ( 1984).

[16] EXTOXNET. Chlorpyrifos, Pesticide Information Profile USDA. (1996).

[17] T.R. Galloway, Randy. Immunotoxicity of organophosphorous pesticides. Ecotoxicicology 12 (2003) $345-363$.

[18] GenStat-Release 4.2 Discovery Edition, VSN-International Ltd, Lawes Agricultural Trust. www.worldforestrycenter.org/genstatforafrica (2006).Accessed December 20, 2008

[19] G.W. Holcombe, G.L. Philipps, D.K. Tanner, The acute toxicity of Kelthane, dursban, disulfoton, pydrin, and permethrin to fathead minnows Pimephales promelas and rainbow trout Salmo gairdneri. Environ. Pollut. 29 (1982) 167-178.

[20] A.W. Jarvinen, D.K. Tanner, E.R. Kline, Toxicity of chlorpyrifos, endrin, or fenvalerate to fathead minnows following episodic or continuous exposure. Ecoxicol. Environ. Saf. 15 (1998) 78-95.

[21] S.D.R. Kumari, K.S. Sreeletha, Respiratory methabolism in Eutroplus maculates (Bloch) under estuarine conditions and pesticide stress. Journal of the Marine Biology Association of India 29 (1992) 226-231.

[22] R. Lloyd, Pollution and Freshwater Fish. Fishing News Book, U.S.A, (1992)

[23] F. Matsumura, Toxicology of insecticides. Plenum press, N.Y.U.S.A. 34. (1975).

[24] I.G. Mbagwu, E.O. Ita, Pesticide use in the sub-humid zones of Nigeria: Implication for conservation of Aquatic Resources. Environmental Conservation 21 (1994) 214-219.

[25] NRA. Review of chlorpyrifos, National Registration Authority for Agricultural and Veterinary chemicals Canberra, Australia. 263 (2000).

[26] E. O. Ogueji, Acute toxicity of "Cypermethrin 10\% EC" and "deltamethrin EC 12" to the African catfish Clarias gariepinus (Teugels) (1997). M.Sc. Thesis zoology Department University of Ibadan

[27] E. Omoregie, E.B.C.Ufodike, Histopathology of Oreochromis niloticus exposed to Actellic 25EC. Journal of Aquatic Sciences. 6 (1991)13-17.

[28] A K. Pal, S. K. Kunar, Long term effect of Organophosphorus insecticide, Methyl parathion on fish. Enviornmental Ecology. 5(3) (1987) 504 -571 .

[29] K.D. Racke, The environmental fate of chlorpyrifos. Rev. Environ. Contam. Toxicol. 131 (1992) 5-52.

[30] G. M. Rand, P. G.Wells, L. S. McCarty, Introduction to aquatic toxicology, pp. 3-67. In: G. M., Rand (ed), Fundamentals of Aquatic Toxicology -Effects, Environmental Fate, and Risk Assessment. Washington, D.C., Taylor and Francis Publishers, 1125 (1995).

[31] D.L. Reish, P.S. Oshida, Manual of methods in aquatic environment research Part 10. Short term static bioassay. FAO. Fisheries. Technical paper 247. FAO Rome 1- 62 (1987). 
[32] J.P. Rice, C.D. Drewes, T.M. Klubertanz, S.P. Bradbury, J.R. Coats, Acute Toxicity and Behavioral Effects of Chlorpyrifos, Permethrin, Phenol, Strychnine, and 2,4-Dinitrophenol to 30-Day-old Japanese Medaka (Oryzias Latipes) Environmental Toxicology and Chemistry: 16 (1996) 696-704.

[33] V. Rukiye, U E. Figen, P. Hilal, K. Oner, Investigation of acute toxicity of deltamethrin on guppies (Poecilia reticularta) Ecotoxicology and EnvironmentalSafty 55 (2003) 82-85.

[34] R. Sarki, Toxicity of organic phosphates and chloronaphthalenes: Part 11. Effect of chlorpyrifos on cholinesterase activity in rats. Okayama Igakkai Zasshi 102 (7-8) (1990). 997-1006

[35] G.N. Smith, B.S. Watson, F.S. Fischer, The metabolism of \{14c $\}$ O,)-diethy 10-(3,5,6- to trichloro -2-pyridyl) phosphorothioate (Dursban) in fish. J. Econ. Entomol. 59 (1966) 1464-1475.

[36] J.B. Spragne, Measurement of pollution toxicity to fish: In Bioassay methods for acute toxicity. Water Resources. 3 (1975) $346-349$. 